\title{
LONG TO SHORT TIME-SCALE FACTORS IN ROCKY COASTS CHANGE IN THE NW SPAIN
}

\author{
R. Blanco ChaO*, M. Valcárcel díaz *, M. Costa Casais** \& A. Pérez Alberti*
}

\begin{abstract}
Processes in rocky coasts operates in a wide range of time-scales, from seconds to millennia, but sealevel oscillations probably are the most significant changes. A portion of land changes from coastal to continental environment as sea-level rise or fall, and, although a re-occupied coast is never the same, it can conserve a memory of the previous morphodynamic states. This memory of the system implies that the processes that operated in the past exert a large influence on present processes. This is a very important factor in the evolution and present dynamics of rocky coasts, in which many erosive and sedimentary landforms are fully or partially inherited. Inheritance also means that past processes and landforms control many processes operating today.
\end{abstract}

Key - words: rocky coasts, inheritance, sea-level.

\section{INTRODUCTION}

The coast of NW Spain can be characterized by its lithological diversity and marked tectonic structure, giving a very irregular planform, with numerous indentations at various scales, from the great rias of the south-atlantic coast, to small inlets. Many rocky sectors alternate with sedimentary complex, usually not too long, but comprising a variety of environments: beaches, lagoons, intertidal flats, dune complex, etc.

Hercynian or late Hercynian granitic rocks, Precambrian schists and basic rocks dominate in western coast of Galicia, and metamorphic Precambrian and Palaeozoic rocks (shales, gneisses, quartzites) in the north (Fig. 1). An extensive network of NW-SE and NE-SW trending faults were produced in the latter phases of the Hercynian orogeny and a group of north-south running fractures developed later in the early Mesozoic because of rifting in the Atlantic. From the Eocene until at least the early Quaternary, intense tectonic movements along the unstable Atlantic margin formed a series of uplifted blocks and basins (PÉREZ AlBERTI, 1991); many of these uplifted blocks have created coastal mountains with elevations between $300 \mathrm{~m}$ and $600 \mathrm{~m}$.

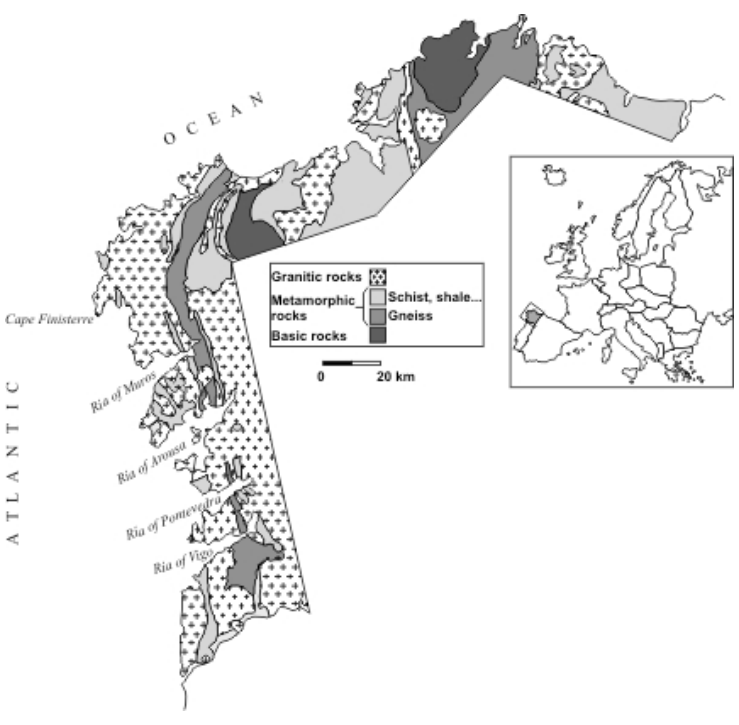

Fig. 1 - Rock types in the coast of Galicia.

This irregular form and the presence of coastal mountains, up to $600 \mathrm{~m}$ high, helped to create very special morphogenic conditions in the southwestern atlantic Europe. The intensity of cold processes during the last glacial sea-level regression generated an extensive sedimentation over abandoned coastal landforms.

\footnotetext{
* Dpto. de Geografía, Universidade de Santiago de Compostela. Praza da Universidade, 1. 15782 Santiago, A Coruña.

** Laboratorio de Arqueoloxía da Paisaxe, Instituto de Estudos Galegos P. Sarmiento. CSIC. Xunta de Galicia. Rúa de S. Roque, 2, 15704 Santiago, A Coruña.

E-mail (following the list of authors): rblanco@usc.es; marcossvd@usc.es; phnuec@usc.es; xepalber@usc.es.
} 
The sequence of fossilization and exhumation of coastal landforms established a para-periglacial (BLANCO CHAO et al., 2007) dynamics in which inheritance it is one of the major factors in recent, present and future behaviour.

Today, the coast of Galicia has a high wave energy environment with marked seasonal behaviour. The highest waves usually occur in autumn and winter with a mean significant wave height (Hs) of $2.34 \mathrm{~m}$, a maximum of $8.95 \mathrm{~m}$, and periods between 7 and $8 \mathrm{~s}: 9 \%$ of the waves have periods of more than $10 \mathrm{~s}$. During the summer the mean $\mathrm{Hs}$ is $1.3 \mathrm{~m}$ with a maximum of $6.62 \mathrm{~m}$, and there is a mean period of $6 \mathrm{~s}$, with less than $1 \%$ of the waves exceeding $10 \mathrm{~s}$ (Puertos del Estado, data from 1991-2003). Spring tidal range often exceeds $4 \mathrm{~m}$ under storm surge conditions on this coast (Puertos del Estado).

\section{INHERITANCE AND SLOW RATE COASTAL CHANGES}

The differences in rates of coastal change between sedimentary and rocky coasts implies that, to try to understand the whole behaviour of this type of coastal systems, long and medium time-scales factors must be considered. Coasts are very complex environments, the interface within seas, continents and atmosphere, in which the memory of the system arises as a basic element (COWELL \& THOM, 1994). This is specially true in rocky coast, because the processes operates in time-scales ranging from seconds to thousand of years, making difficult the monitoring of rocky systems and the acquisition of quantitative data (TRENHAILE, 1997, 2002).

In rocky coastal sectors many landforms are in part inherited, relict or polygenetic, so it is difficult to acquire quantitative data on them, given the wide range of time and space scales in which processes operates (TRENHAILE, 1997, 2002). Rock processes range from almost imperceptible changes due to tidal wetting and drying weathering or abrasion to fast events mobilizing tons of rock caused by low frequency-high energy storms. If these slow changing coasts remained fossilized for thousand of years, they can preserve signs of past environments and processes very different to those operating in the present. The rising sea-level during the Holocene transgression simply exhumed many rocky sectors in the coast of Galicia, and therefore the observed landforms in the present coastline are mostly inherited and not modelled during the Holocene. Furthermore, past processes and environmental conditions are still influencing present morphodynamics.

\section{THE LAST INTERGLACIAL AND THE GLACIAL MARINE REGRESSION}

Sea-level was similar to today during Isotopic Stages 11, 9 and at least the substage 5e (ShACKLETON \& OpDYKe, 1973). Recently, these relative sea-levels are being revised, and probably there were more interglacial periods with sea-level close or higher than today in the Early and Middle Pleistocene, as well as during substages of the last interglacial always assumed as lower sea-levels as the $5 \mathrm{c}$.

The marine regression during the last glaciation was followed by the glacial climatic deterioration, which leads to a severe instability of the slopes close to the abandoned coast. During the last glaciation, three main cold phases stand out as responsible for significant slope instability (PÉREZ AlberTi \& VALCARCEL DíAZ, 1998). The first phase, prior to $31 \mathrm{ky}$ BP was very humid, showing a decrease in the mean annual air temperature (MAAT) of about $6{ }^{\circ} \mathrm{C}$ compared to present average annual temperature values. The second cold period coinciding with the maximum glacial stage, had a more continental character, but showing a significant descend in MAAT of about $12{ }^{\circ} \mathrm{C}$. The last phase presents two episodes, the first around 16-13 ky BP, with a temperature decrease of up to 6-7 ${ }^{\circ} \mathrm{C}$ and the second in 11-10 ky BP, with a $4{ }^{\circ} \mathrm{C}$ decrease in MAAT.

The indented coast and the existence of coastal mountains, sets up a very favourable context for the creation of a morphogenetic environment dominated by cold processes, which resulted in a high instability of the slopes. From $38 \mathrm{ky}$ BP to the Late-Glacial (10 ky BP) thick deposits were formed on the abandoned coast, fossilizing the former coastal landforms. The thickness and facies of such deposits are controlled by their position, source of the materials and distance to the source area (COSTA CASAIS et al., 1994, 1996a, 1996b; PÉREZ AlBERTI et al., 1997, 1998a, 1998b, 1998c; TRENHAILE et al., 1999).

From the north coast of Galicia to the mouth of Miño river there are a number of erosive and sedimentary coastal features modelled with a sealevel 2-3 m higher than today. The features include cliffs, sea-caves, narrow inlets, shore platforms and boulder beaches, many of them with evidences of having been fossilized by continental sediments deposited during the last glaciation (Fig. 2).

The features include composite or slope-overwall cliffs, composed of a basal scarp and an upper concave slope covered by continental sediments. There are also sea-caves and narrow inlets opened following a fracture or a lithological contact (in Galician language named furnas) with their bottom in filled by thick periglacial sediments. Many shore 


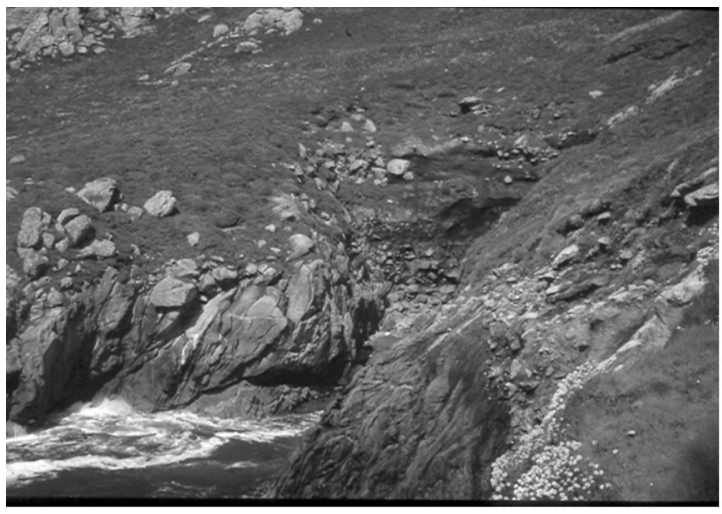

a)

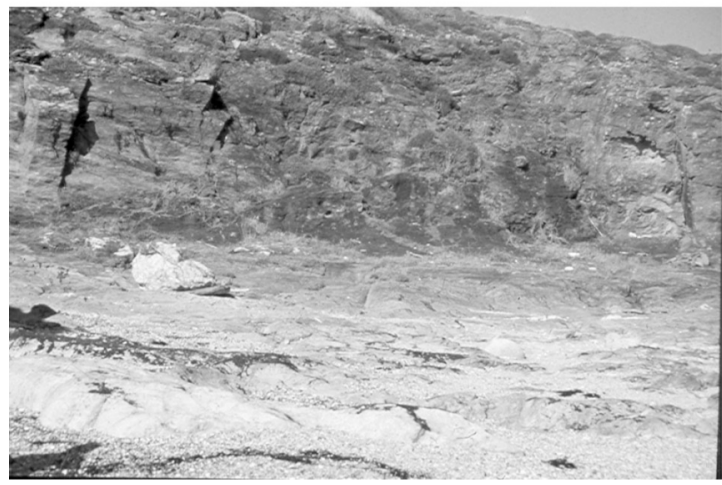

b)

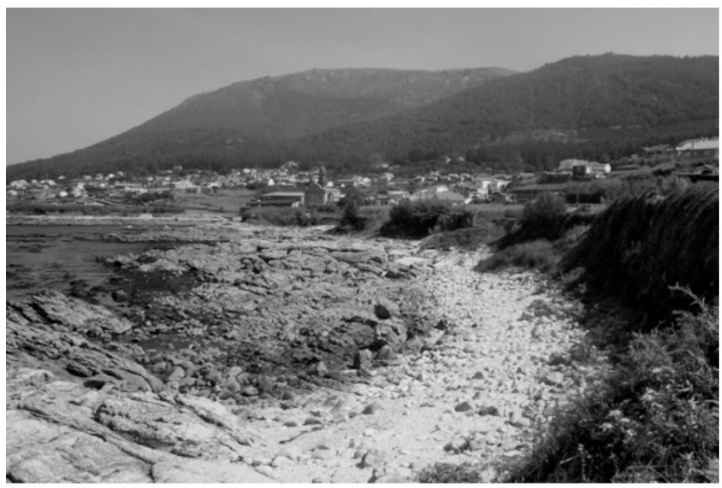

d)

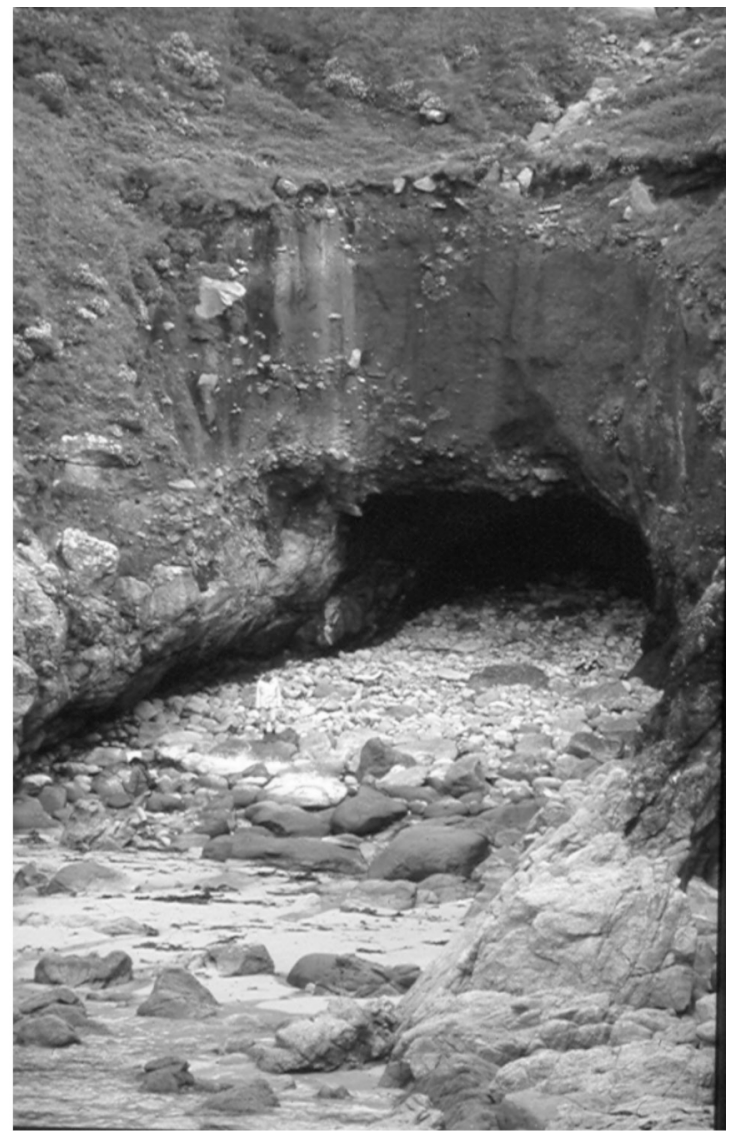

c)

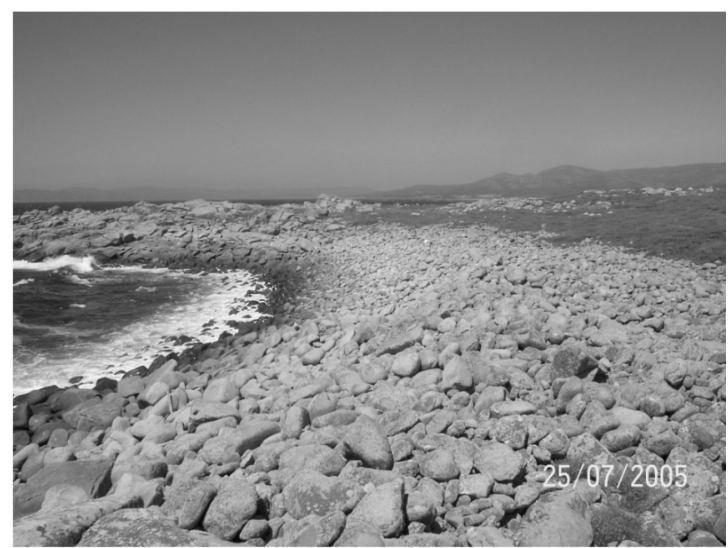

e)

Fig 2. a) Composite or Slope-over-wall cliff in Pta. Roncudo, with periglacial deposits in the upper slope. b) Paleo cliff-platform junction, $2.5 \mathrm{~m}$ above the present spring high tide level. c) Deep inlet filled with periglacial continental sediments. The sediments were eroded developing a sea-cave at the base. The coarse-grained beach is derived from the erosion of the continental sediments. d) Cliff deposits at Oiã stabilized by terrestrial vegetation. The platform at the front was exhumed when the continental sediments were eroded, supplying clasts for the boulder beach. e) Boulder beach with the crest $3 \mathrm{~m}$ above high tide level. The boulders are covered by lichens, and infilled in part with continental sediments. Only the most seaward edge of the beach is active today. 
platforms shows an upper segment above the mean high tide level, narrower and steeper than the present intertidal segments, backed by cliff deposits or by boulder beaches. The cliff deposits that fossilize the platforms or inlets varies in thickness and facies, but is possible to make a stratigraphical correlation between them, using facies sedimentological criteria and the existing ${ }^{14} \mathrm{C}$ datations. It is very common to find beach levels, with sizes from coarse sand to pebbles and boulders at the base of these continental sediments (Trenhaile et al., 1999; CostA CASAIS et al., 1996a; PÉrez AlBERTi et al., 1998b; BlanCO CHAO et al., 2002, 2003).

There are many places with boulder beaches at elevations between 2 and $3 \mathrm{~m}$ above present high tide level, in places in which today marine erosion is not important, and the sediment supply is zero. Lichen and terrestrial plants colonize the crest and upper shoreface of these boulder beaches, and the landward portions are partially fossilized by continental sediments. Only the lower portions, between mean and spring high tide levels, are active.

Meanwhile in the Portuguese and the cantabrian coast the existence of neotectonic movements has been proved (EDESO et al., 1990; CEARRETA \& PASCUAL, 1990; CEARRETA et al., 1992; MARY 1970, 1983; ARAÚJO, 1991, 1996, 2004; GRANJA et al., 1996) the present evidences suggest a tectonic stability in the coast of Galicia, at least since the last interglacial. The sea-level references points to the occurrence of uplifting movements on the Spanish north coast and Portuguese north coast after the last interglacial, which diminishes in intensity westwards and probably, but in a more complex way, northwards. Thus, the Galician coast would have remained stable, being the NW of the Iberian Peninsula a sort of pivotal axis, which allowed the coastal landforms to remain in their original place (PÉREZ AlBERTI et al., 1999).

\section{The Holocene transgression AND THE PARA-PERIGLACIAL DYNAMICS}

Unfortunately, there is no a detailed sea-level curve for the Holocene for the coast of Galicia. Nevertheless, many authors suggest that sea-level reached its present position around $3000 \mathrm{BP}$, although many coastal systems began to develop before, around $5000 \mathrm{BP}$, coinciding with the deceleration of the sea-level rise (BAO et al., 1999; DiAS et al., 2000; DELGADO et al., 2003; FREITAS et al., 2003, LEORRI \& CEARRETA, 2004).

The Holocene transgression represented the beginning of a para-periglacial dynamics, in which the continental deposits that fossilized the ancient coastline were eroded by the rising sea-level. Given the differences in extension, thickness, facies and settings of the deposits, the retreat was irregular both in space and in time, and was controlled by the volume and nature of the sediments, the energetic environment and the exhumation of fossilized landforms. In the cliff deposit of Oiã a sample taken at $45 \mathrm{~cm}$ from the top surface of the deposit gave a ${ }^{14} \mathrm{C}$ date of $1794 \pm 75$ BP (Ua-33776), and in Caamaño three samples taken at 100, 160 and 215 $\mathrm{cm}$ from the top of the cliff gave ${ }^{14} \mathrm{C}$ dates of $530 \pm 80(\mathrm{GrN}-22279), 2720 \pm 140(\mathrm{GrN}-22280)$ and $3404 \pm 82$ years BP (Ua-33774). The radiocarbon dates proved the existence of continental sedimentation followed by the erosion of the cliffs until very recent times (TRENHAILE et al., 1999; BlANCO CHAO et al., 2002, 2003).

Many cliff-deposits are today stabilized, covered by terrestrial vegetation and out of the wave attack, but many others sectors show evidences of continuous erosion by waves or evidences of episodic instability. As they are in the last phase of the para-periglacial period, today many processes are still controlled by the combination of inherited landforms and the disposal of sediments in periglacial cliff deposits. For example, it was found that some erosive processes as abrasion or the degree of rock weathering in intertidal shore platforms are today conditioned by the very recent retreat of cliff-deposits (BLANCO CHAO et al., 2006, 2007). The present abrasion activity is in part conditioned by the recent redistribution of clasts over an exhumed platform, and in some cases, the presence of boulder lags determined where the abrasion is effective or not. As intense mechanical erosion is a handicap for the intertidal organisms, the existence or inexistence of abrasion plays also a role in the biological coverage of rocky intertidal sectors.

The equilibrium is still fragile, and any variation in present conditions could lead to significant environmental changes. The effects of future sealevel rise are generally considered as the main hazard derived of global warming, but in many rock coasts a sea-level changes of a few centimetres could have less effects than an enhanced wave energy caused by an increase in storm frequency and intensity. On the other hand, the amount of sediment still available in continental deposits could be one of the best defences, as they can retreat and supply new sediment for beach nourishment.

\section{Conclusions}

The title of this paper refers to the short and long time-scale factors that have influence on the morphodynamics of rocky coasts. There is no doubt 
that the type of rock and the structural factors as major faults and fractures, or the direction and dip of strata and schistosity planes in metamorphic rocks are one of the main factors in the longest time scales. The other main factor in long time-scales is, of course, sea-level changes. The amplitude of sealevel changes during the glaciation caused a drastic change from a temperate coastal to a periglacial continental morphogenetic environment. This change didn't cause a widespread destruction of former coastal landforms or deposits, but preservation by fossilization.

The rising sea-level in the Holocene found a enormous amount of continental sediments, which were eroded until the sea-level stabilization. As the Pleistocene sediments were eroded, the ancient coastal landforms were exhumed which allows defining them as inherited landforms.

In the shorter time-scale comprising the period between sea-level stabilization and the present, the release of coarse sediments by the erosion of deposits was one of the major factors. Beach development and changes in the intensity and frequency of erosive processes as abrasion, or the development of a dense biological coverage in the intertidal zone were controlled by the availability and size of this sediments delivered from cliff deposits.

\section{REFERENCES}

ARAÚJO, M.A. (1991). Evolucão geomorfológica da plataforma litoral da região de Porto. Tese de Doutoramento Universidade de Porto.

ARAúJO, M.A. (1996). Paleoambientes fini-terciários e quaternarios no litoral da região do Porto, in A. Pérez Alberti, P. Martini, W. Chesworth \& A. Martínez Cortizas, (eds.) Dinámica y evolución de medios Cuaternarios. Xunta de Galicia, Santiago, pp. 359-373.

AraÚJO, M.A. (2004). O litoral $\mathrm{N}$ de Portugal e os depósitos cenozoicos da regiao do Porto: a tectónica e o eustatismo, in R. Blanco Chao, J. López Bedoya y A. Pérez Alberti (eds.). Procesos geomorfológicos y evolución costera. Actas de la II reunión de Geomorfología Litoral, Santiago, Servicio de Publicacións da USC. Santiago.

BAO, R.; Freitas, M.C. \& ANDRADE, C. (1999). Separating eustatic from local environmental effects: a late Holocene record of coatal change in Albufeira Lagoon, Portugal. The Holocene, 9 (3), pp. 341-352.

Blanco ChaO, R.; Costa Casais, M.; Martínez Cortizas, A.; Pérez Alberti, A. \& VÁzQuez PAZ, M. (2002). Holocene evolution in Galician coast (NW Spain): an example of paraglacial dynamics. Quaternary International, 93-94, pp. 149-159.

Blanco ChaO, R.; Costa Casais, M.; Martínez Cortizas, A.; PÉrez Alberti, A. \& Trenhaile, A.S. (2003). Evolution and inheritance of a rock coast: western Galicia, northwestern Spain. Earth Surface Processes and Landforms, 28, pp. 757-775.
Blanco Chao, R.; PÉrez Alberti, A.; VAlCÁrcel DíAz, M. \& Costa CASAIS, M. (2006). Alteración y abrasión en plataformas litorales: Canal Beagle (Argentina) y costa NW de la Península Ibérica, in A. Pérez Alberti \& J. López Bedoya (eds.) Geomorfología y Territorio. Servicio de Publicacións da USC, Santiago, pp. 323-336.

Blanco Chao, R.; Pérez Alberti, A.; Trenhaile, A.S.; Costa CASAIS, M. \& VAlCÁRCEL DÍAZ, M. (2007). Shore platform abrasion in a para-periglacial environment, Galicia, northwestern Spain. Geomorphology, 83, pp. 136151.

Cearreta, A. \& Pascual, A. (1990). Estudio micropaleontológico de los depósitos cuaternarios litorales situados entre Laredo e Ibarrangelua (Cantabria y Bizkaia), El cuaternario en España y Portugal. Actas de la II Reunion del Cuaternario Ibérico, Madrid, pp. $307-$ 323.

Cearreta, A.; Edeso, J. M. \& Ugarte, F. (1992). Cambios del nivel del mar durante el Cuaternario reciente en el golfo de Bizkaia, in A. Cearreta \& F. Ugarte (eds.) The Late Quaternary in the Western Pyrenean Region. Servicio Editorial, Universidad del País Vasco, Bilbao, pp. 57-94.

Costa CAsais, M.; Martínez Cortizas, A. \& PÉrez Alberti, A. (1994). Caracterización de un depósito costero de la Ría de Muros-Noia (La Coruña, Galicia), in J.M. ArnaezVadillo, J.M. Garcia-Ruiz \& A. Gomez Vilar (eds.) Geomorfología en España, Tomo II. SEG. Logroño, pp. 355-368.

Costa Casais, M.; Martínez Cortizas, A. \& PÉrez Alberti, A. (1996a). Tipos de depósitos costeiros antiguos entre o Cabo de Fisterra e o de Corrubedo, in A. Pérez Alberti, P. Martini, W. Chesworth \& A. Martínez Cortizas (eds.) Dinámica y evolución de medios Cuaternarios, Xunta de Galicia, Santiago, pp. 417-430.

Costa Casais, M.; Moares Domínguez, C. \& Martínez CORTIZAS, A. (1996b) Caracterización físco-química do depósito litoral de Mougás (Pontevedra): implicacións morfoxenéticas, in A. Pérez Alberti, P. Martini, W. Chesworth, A. Martínez Cortizas (eds.) Dinámica $y$ evolución de medios Cuaternarios, Xunta de Galicia. Santiago, pp. 431-440.

Cowell, P.J. \& ThOM, B.G. (1994). Morphodynamics of coastal evolution, in R.W.G. Carter and C.D. Woodroffe (eds.) Coastal evolution. Late Quaternary shoreline morphodynamics. Cambridge University Press, pp.33-86.

Delgado, C.; BaO, R.; Alonso, A. \& PAgÉS, J.L. (2003). Evolución paleoambiental inferida por diatomeas de la laguna costera de Traba (A Coruña, NO España) durante los últimos 5000 años, in G. Flor (ed.) Actas de la XI Reunión Nacional del Cuaternario. Principado de Asturias, Consejo de Candamo, Cajastur.

Dias, J.M.A.; Boski, T.; Rodrigues, A. \& Magalhaes, F. (2000). Coast line evolution in Portugal since the Last Glacial Maximum until present - a synthesis, Marine Geology, 170, pp. 177-186.

Edeso, J. M.; PeÑalba, C. \& UGarte, F.M. (1990). El depósito detrítico pleistoceno de Anzaran (Irún), estuario del Bidasoa: caracterización, geomorfológica y palinológica, El cuaternario en España y Portugal Actas de la II Reunion del Cuaternario Ibérico, Madrid, pp. 191-199.

Freitas, M.; ANDRADE, C.; Rocha, F.; TASSINARI, C.; MunhÁ, J.M.; CRUCES, A.; VidinhA, J. \& DA Silva, C.M. (2003) Lateglacial and Holocene environmental changes in Portuguese coastal lagoons 1: the sedimentological and geochemical records of the Santo André coastal area. The Holocene, 13 (3), pp. 433-446. 
Granja, H.M. \& Thomas, A.M. DE Groot, (1996). Sea-level rise and neotectonism in a Holocene coastal environment at Cortegaça Beach (NW Portugal): a case study. Journal of Coastal Research, 12 (1), pp. 160-170.

LEORRI, E. \& CEARretA, A. (2004). Holocene environmental development of the Bilbao estuary, northern Spain: sequence stratigraphy and foraminiferal interpretation, Marine Micropaleontology, 51, pp. 75-94.

MARY, G. (1970). La rasa cantabrique entre Luarca et Ribadeo (Asturies, Espagne), Breviora Geológica Astúrica, 4, pp. $45-48$.

MARY, G. (1983). Evolución del margen costero de la Cordillera Cantábrica en Asturias desde el Mioceno, Trabajos de Geologia, 13, pp. 3-35.

Perez AlBerti, A. (1991). La geomorfología de la Galicia Sudoriental (Problemas geomorfológicos de un macizo antiguo de la fachada atlántica Ibérica: centro-sudeste de Galicia). Tesis Doctoral. Universidade de Santiago. Inédita.

PÉreZ Alberti, A. \& VAlCÁRCEl DíAZ, M. (1998). Caracterización y distribución espacial del glaciarismo en el noroeste de la Peninsula Ibérica, in A. Gómez Ortíz \& A. Pérez Alberti (eds.), Las Huellas Glaciares de las Montañas Espanñolas, Universidad de Santiago, pp. 1762.

Pérez Alberti, A.; Blanco ChaO, R. \& Costa Casais, M. (1997). La importancia de los balances de acumulación/erosión y fosilización/exhumación en la evolución geomorfológica de la costa de Galicia. Dinámica Litoral-Interior. Actas del XV Congreso de Geógrafos Españoles, Vol. I., pp. 205-219.
Pérez Alberti, A., Blanco Chao, R. \& Costa Casais, M. (1998a). Depósitos sedimentarios antiguos en la costa atlántica gallega: tipología, localización y área fuente. Un análisis comparativo, in A. Gómez Ortiz \& F. Salvador Franch (eds.) Investigaciones Recientes de la Geomorfología Española. Universitat de Barcelona, Barcelona, pp. 341-346.

Pérez Alberti, A.; Blanco ChaO, R.; Costa CASAis, M. \& VÁZQUEZ PAZ, M. (1998b). Formas litorales heredadas en costas rocosas de Galicia, in A. Gómez Ortiz \& F. Salvador Franch (eds.) Investigaciones Recientes de la Geomorfología Española. Universitat de Barcelona, Barcelona, pp. 333-339.

Pérez Alberti, A.; Costa Casais, M. \& Blanco ChaO, R. (1998c). L'importance des processus d'origine froide sur la cote atlantique de la Galice (Nord-ouest de la Peninsule Iberique, Environnements periglaciaires, Vol. 5, pp.21-32.

Pérez Alberti, A.; Costa CASAis, M. \& Martínez Cortizas, A. (1999). Nuevas aportaciones al conocimiento del cuaternario reciente en la costa atlántica de Galicia, Geoarqueología $i$ Quaternari litoral. Memorial M.P. Fumanal, pp. 381-390.

Shackleton, N.J. \& OpdYKe, N.D. (1973). Oxygen isotope and palaeomagnetic straitgraphy of Equatorial Pacific core V28-238: Oxygen isotope temperatures and ice volumes on a 105 year and 106 year scale, Quaternary Research, 3, pp. 39-55.

Trenhaile, A.S. (1997). Coastal dynamics and landforms. Clarendon Press. Oxford.

TRENHAILE, A.S. (2002). Rock coasts, with particular emphasis on shore platforms, Geomorphology, 48, pp. 7-22.

Trenhaile, A.S.; Pérez Alberti, A.; Martínez Cortizas, A.; Costa Casais, M. \& Blanco ChaO, R. (1999). Rock coast inheritance: an example from Galicia, Northwestern Spain, Earth Surface Processes and Landforms, 24, pp. 605-621. 